\title{
The Effectiveness of Booklets in Stimulation, Detection and Early Intervention of Growth and Development (SDEIGD) for Health Cadres in Implementing the Growth and Development Screenings of Toddlers
}

\author{
Monalisa; Ernawati; Wilda Sinaga; Abbasiah \\ Department of Nursing, Health Polytechnic of Jambi, Indonesia \\ http://dx.doi.org/10.18415/ijmmu.v8i9.2919
}

\begin{abstract}
The importance of monitoring the growth and development of early childhood is helpful for all parties involved, especially for Health Integrated Service (HIS), teachers, parents, and the children themselves. HIS is expected to determine what steps or efforts can be taken in helping children's development because from the family, in this case, the parents, the beginning of growth and development begins. The purpose of this study was to develop a Booklet of Stimulation, Detection and Early Intervention on Growth and Development (SDEIGD) for health cadres in the implementation of screening for growth and development of toddlers. This study involved 32 health cadres in the Aur Duri Public Health Center Jambi City working area as the intervention group and the Penyengat Olak Jambi Health Center as many as 32 people as controls. This research will be conducted in August 2019 at the Putri Ayu Public Health Center, Jambi City. There are two stages in this study, consisting of the instrument preparation stage and administrative preparation. The next stage is the implementation which consists of making booklets for Health integrated services cadres, enriching and developing the skills of Health integrated services cadres, small group discussions, practicum and simulation of the implementation of growth and development stimulation, early detection and screening of growth and development, early intervention on growth and development in children aged 0-6 years, and knowledge measurement. Data were analyzed using the Shapiro-Wilk test at a 95\% confidence level $(\alpha \leq 0.05)$. The results of the validation of materials experts and linguists, it is known that the SDEIGD booklet media meets the criteria and is worthy of being a guide for health cadres in understanding Stimulation, Detection, and Early Intervention of Toddler Development. The media trial starting from small groups, large groups and understanding tests of SDEIGD material indicate that the SDEIGD Media Booklet is worthy of being a handbook for health cadres for the implementation of screening for toddlers growth and development.
\end{abstract}

Keywords: Stimulation Booklet; Detection; Early Intervention on Growth and Development; Health Cadres

\section{Introduction}

A critical period in a child's growth and development is the toddler period because, at this time, there is primary growth that will influence and determine the next child's development (Alifariki, 2020; Palasari \& Purnomo, 2012; Revika et al., 2019). At this time, the development of language skills, creativity, social awareness, emotional and intelligence dashes and is the basis for subsequent 
developments. Moral development and the basics of personality are also formed at this time(Fernald et al., 2008). Even a statement that says, "The child is the father man" so that every slightest abnormality/deviation if it is not detected or not handled properly will reduce the quality of human resources in the future (Soetjiningsih, 2012).

The process of child growth and development in the first three years of life is a critical period that must be monitored and appropriately recorded. The goal is to find developmental disorders early for carrying out treatment as early as possible before the child passes his critical period (Léger et al., 2014).

Comprehensive and quality development of children's development carried out through stimulation activities, early detection and intervention of deviations in growth and development of toddlers is carried out in the first five years of a child's life as a golden period or window of opportunity, or a critical period (Attanasio et al., 2014).

There are several efforts to help children grow and develop optimally, one of which is through detection of deviations and early intervention that needs to be carried out by all parties, including families, health workers (health cadres to specialists), and at all levels of health services starting from the primary level to more specialized services (Hendrawati et al., 2018; Permono, 2013).

The Stimulation, Detection and Early Intervention of Growth and Development (SDEIGD) is one of the leading programs of the PHC. This activity is carried out in a comprehensive and coordinated manner held in the form of a partnership between the family (parents, child caretakers, and other family members), the community (cadres, professional organizations, and non-governmental organizations) professional staff. Monitoring children's growth and development through early detection of growth and development is part of the task of Health Integrated Service (HIS) cadres to detect early developmental delays in children. HIS, as a form of community participation in activities under the Ministry of Health, is one of the most basic levels of implementing public health education and monitoring (Kemenkes RI, 2018).

Through SDEIGD activities, the worst conditions of growth deviations in children, such as malnutrition, can be prevented because before a child falls into a condition of malnutrition, growth deviations that occur in children can be detected. In addition to preventing growth deviations, SDEIGD activities also prevent developmental deviations and mental, emotional deviations (Kemenkes RI, 2016). Early detection through SDEIGD activities is vital to finding early growth deviations, developmental deviations, and mental and emotional deviations in children. Intervention and stimulation can be carried out as early as possible to prevent growth deviations, developmental deviations and permanent mental, emotional deviations. SDEIGD activities are carried out on children suspected of having problems but must be carried out on all toddlers and preschoolers regularly, which is carried out twice a year (Kemenkes RI, 2016; Padila et al., 2019).

Based on the interviews with health workers at PHC, it was found that SDEIGD formats consist of many items that would not be efficient to screen all children under five. For this reason, some implementers only screen children who are suspected of experiencing developmental delays (Maritalia, 2009). Stimulation, detection, and early intervention on growth and development at HIS are not complete, only weighing and measuring height (Khairunnisa et al., 2018). Posyandu cadres have not been able to carry out early detection and early intervention for developmental deviations comprehensively because of the difficulty in understanding modules whose concepts are pretty numerous and packaged less simply for health cadres (Sari \& Haryanti, 2019). HIS cadres in the PHC work area expect to be fostered by health workers to have the knowledge and skills in stimulating, detecting, and intervening in children's growth and development, especially children aged 0-6 years (Kemenkes RI, 2016). 
Based on this phenomenon, we develop the SDEIGD booklet for health cadres in the implementation of screening for the growth and development of Toddlers in the working area of Putri Ayu Public Health Center, Jambi City.

\section{Methods}

This study is a quasi-experimental model using a non-equivalent control group design. In the experimental group, learning uses the SDEIGD booklet, which has been arranged systematically, and for the control group using conventional teaching and learning activities using the SDEIGD Module printed by the Indonesian Ministry of Health.

This study involved 32 health cadres in the working area of the Aur Duri Public Health Center Jambi City as the intervention group and the Penyengat Olak Jambi Health Center as many as 32 people as the control group. This research was conducted in August 2019.

The stages in this study consisted of the instrument preparation stage and administrative preparation. At the instrument stage, the materials needed for the development of the instruments used for data collection were in the form of questionnaires on respondent characteristics, SDEIGD booklets, booklet understanding measurement tools and growth development screening tools. At the administrative preparation stage, the research permit was submitted to the Head of the Putri Ayu Health Center, Jambi City.

Implementation phase consist of:

1. Development of a booklet for HIS cadres regarding SDEIGD in children aged 0-6 years. In this activity, an expert panel was conducted by the research implementation team involving child development experts to create an applicative module specifically made for SDEIGD guidelines for children aged 0-6 years. HIS cadres then use this module for SDEIGD screening.

2. Enrichment and development of the skills of HIS cadres on stimulating growth and development, early detection and intervention of growth and development in children aged 0-6 years using the SDEIGD booklet.

3. Small group discussion, practicum and simulation of the implementation of growth and development stimulation, early detection and screening of growth and development, and early intervention on growth and development in children aged 0-6. This activity is a continuation of the previous activity. After HIS cadres received material on growth stimulation, early detection of growth and development, and early intervention on growth and development, HIS cadres then conducted small group discussions, practicums, and simulations to stimulate, detect, and intervene early on growth and development in children. The purpose of this activity is to increase the psychomotor abilities or skills of cadres in the ability to stimulate, detect problems or deviations in children's growth and development, and make appropriate interventions.

4. HIS cadres are also trained to perform the early intervention in children who are detected to have growth and development deviations that are not under their age. This early intervention aims to correct, improve, and overcome the problem of developmental deviations so that children can grow and develop optimally according to their potential.

5. Measurement of knowledge in this activity was obtained using pretest and posttest questionnaires. The questionnaire was developed from the SDEIGD guide published by the Indonesian Ministry of Health (2016). In contrast, the measurement of psychomotor abilities is based on the observation checklist sheet. This questionnaire includes knowledge and skills regarding stimulation, detection, 
and early intervention on growth and development in children covering aspects of fine motor and gross motor skills, language, personal-social, and independence. This questionnaire was filled out twice, namely before being given training (pretest) and after being given training (posttest). Data were analyzed using univariate analysis with frequency distribution.

Data analysis consisted of two, namely univariate analysis to describe the characteristics and research variables, then bivariate analysis to analyze the relationship between variables. Before the bivariate analysis was carried out, the data normality test was first performed using the Shapiro-Wilk test because the number of samples was less than 50 at the $95 \%$ confidence level $(\alpha \leq 0.05)$.

\section{Results and Discussion}

The explanation of the current study results consisted of analyzing the needs/characteristics of cadres, formulating learning objectives, formulating material items, compiling evaluation instruments, making media, validation by experts and conducting field trials through small group trials and large group trials to determine their understanding of SDEIGD media booklet.

\section{Development Phase}

Learning media development design: SDEIGD booklet refers to the media development design from Sadiman et al. (Arief Sadiman, 2007), which includes analyzing the characteristics of health cadres, formulating learning objectives, formulating material items, compiling evaluation instruments, making media, and evaluating.

\section{Analysis of the Needs and Characteristics of Health Cadres}

Monitoring children's growth and development through early detection of growth and development is part of the task of HIS cadres to detect early developmental delays in children. As a form of community participation in activities under the Ministry of Health, HIS is one of the most basic levels of implementing public health education and monitoring (Kemenkes RI, 2016).

Based on the results of interviews with UPTD officers of the Aur Duri Health Center as the Maternal and Child Health program organizer, monitoring the growth and development of Toddlers at PHC has not been optimal. The lack of implementation of growth and development activities occurs because of the limited number of health workers who are responsible for the implementation of growth and development, and health workers are only limited to carrying out immunization activities, weighing weight and measuring height, while for the implementation of growth and development screening it is not usually carried out. The empowerment of health cadres at HIS is also more focused on providing Vitamin A capsules, immunizations, and weighing toddlers. There are 32 health cadres at the Aur Duri Health Center, and the cadres are pretty active in participating in various health activity programs that can increase their capacity but have never received SDEIGD training. Based on interviews with five health cadres, it is known that they have never carried out screening for toddler growth and development because they do not understand how to carry out these early detection activities. Most health cadres have never seen the guidebook for the implementation of growth and development screening, especially those used for health cadres. This limited information makes health cadres unable to play a role in implementing growth and development screening at PHC. The SDEIGD Handbook for health workers contains growth, development, detection, stimulation of growth and development and attachments to tables and graphs related to growth and development. However, due to a large amount of information in the manual, most cadres are not interested in learning it, plus there is no special training for cadres in understanding the SDEIGD manual. 
All health cadres at PHC Aur Duri are housewives. On average, they have been health cadres for approximately five years, health cadres have served at PHC for a maximum of 12 years, and the newest health cadres have served for two years. The average cadre is 30 years old with an average educational background of high school (SMA), and most of them have a local cultural background, namely the Malay ethnic group.

\section{Learning Objectives}

The objectives of this learning media are to make a learning media (booklet) that is practical and easy to use for health cadres by reading it. It is expected that at least $80 \%$ of health cadres can understand booklets about stimulation, detection and early intervention of growth and development so that the implementation of screening growth and development in PHC Aur thorn can be carried out according to standards.

\section{Formulate the Material Items}

The topics that will be developed in this booklet are about the following materials:

a. Growth and Development

In the development of this media, short text and pictures of the growth and development of Toddlers are used.

b. Growth Measurement

In the development of the booklet media, a short text and a flowchart of ways to assess toddlers' growth are given, using case examples and how to read the nutritional status table of toddlers.

c. Progress screening with KPSP

This media uses case examples about toddler growth and development, and then they are guided to fill out early detection of growth and development (EDGD) form, starting from filling out questionnaires and how to interpret.

d. Stimulation of growth

Stimulation of growth and development is explained in a short text, while the attachment of the stimulation method for each stage of growth and development still refers to the SDEIGD guidelines from the Ministry of Health.

\section{Develop Evaluation Instruments}

The measuring tool for the success of a media can be in the form of tests or assignments. The evaluation instrument compiled here is in the form of a questionnaire containing 10 (ten) questions about the understanding of health cadres about the SDIDTK booklet. Questions related to the suitability, feasibility, and ease of learning media to understand. The evaluation instrument for large groups was added with four questions about essential competencies in pre and post-tests. Questions consist of understanding growth, understanding development, how to measure growth, and how to measure development in Toddlers.

\section{Drafting the Script/ Media}

The manuscript contains information regarding SDEIGD. The information provided in the booklet media is in the form of text and images combined in such a way so that it becomes systematic information. When creating information about the Golden Period, the information is in the form of the following images and text: 


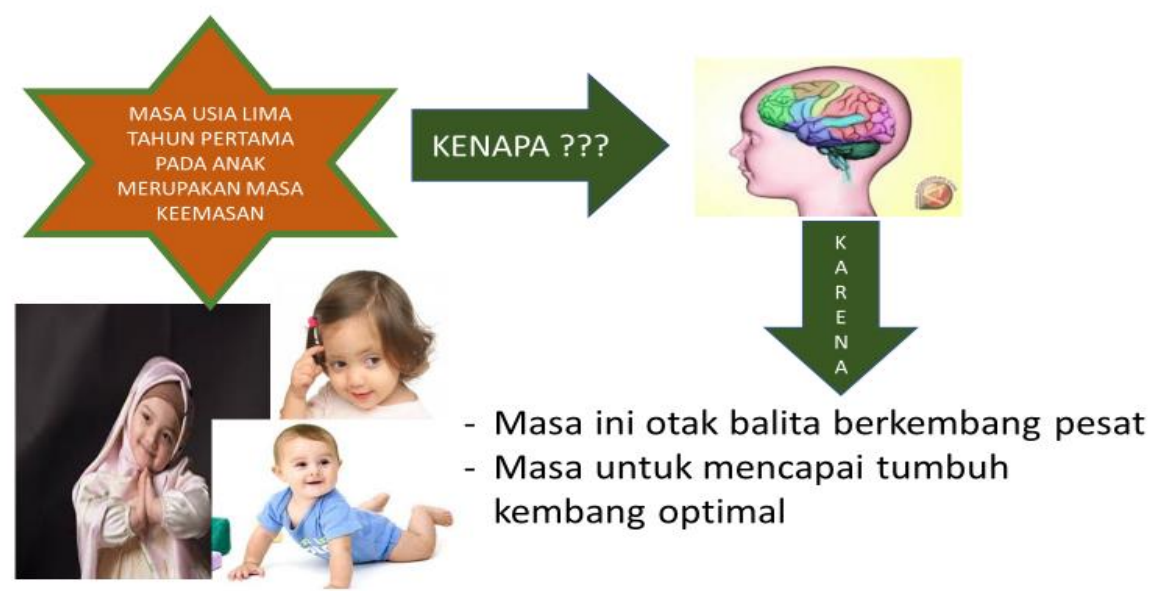

Explanation of the child's nutritional status table to determine the child's growth in the form of a table with the following instructions:

\section{CARA MEMBACA TABEL BERAT BADAN MENURUT PANJANG BADAN/TINGGI BADAN}

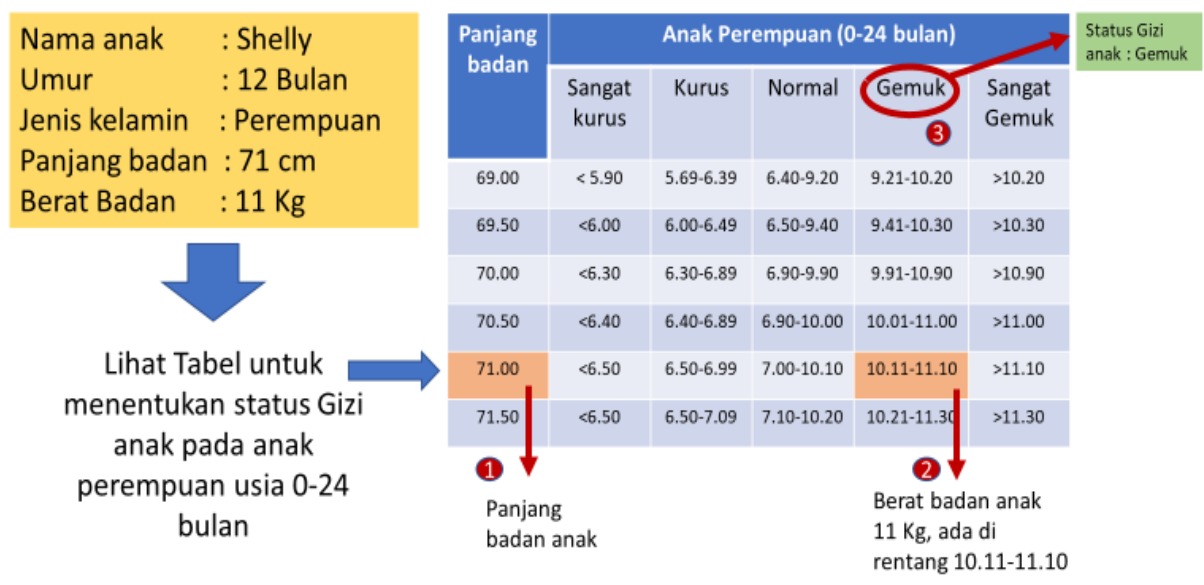

The explanation for reading the early detection form for growth and development after measuring the child's height and weight is as follows:

\section{Lengkapi hasil pengukuran TB dan BB pada Formulir}

\begin{tabular}{|c|c|}
\hline 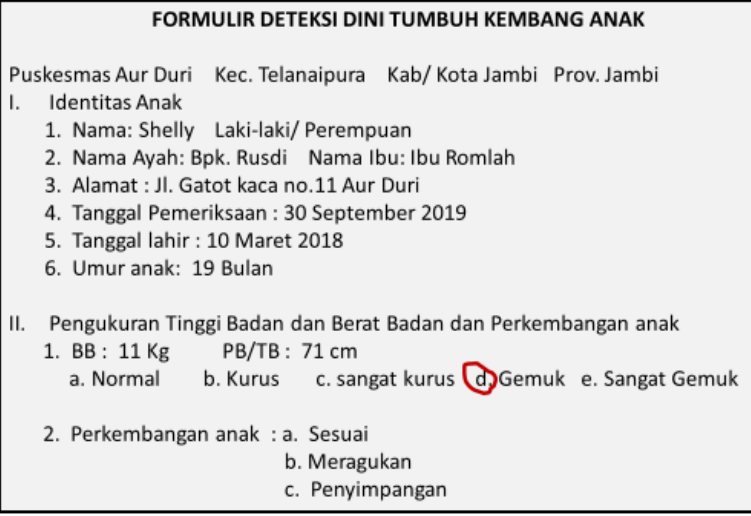 & $\begin{array}{l}\text { Selanjutnya } \\
\text { lakukan penilaian } \\
\text { Perkembangan } \\
\text { anak }\end{array}$ \\
\hline
\end{tabular}




\section{Validation by Expert}

a. Material expert

Material validation was carried out by growth and development experts in Jambi Province. According to the material expert, the SDEIGD booklet media conforms with the SDEIGD standard guidelines regarding truth, adequacy and accuracy. The expert considered the booklet to be $100 \%$ feasible as material for understanding SDEIGD for health cadres.

b. Lingustic expert

According to linguists, using language based on word choice, use of sentences, punctuation marks and relationships between paragraphs $80 \%$ has met the standard of good Indonesian. This Media Booklet is considered appropriate in terms of language to be conveyed to health cadres.

\section{Trials}

The trials were conducted in small groups and large groups. Small groups consist of individuals and three health cadres. After that, a large group trial was conducted on 20 health cadres.

The aspects observed in the small group trial were the attractiveness of booklets, interactivity, ease of understanding, and booklet media's role in the learning process. The number of questions in the questionnaire is 10 (ten) questions with the highest weight for each item is 2 (two). The highest score is 20 , obtained from multiplying the highest weight $\mathrm{x}$ number of samples $\mathrm{x}$ number of questions, then $2 \mathrm{x} 1$ $\mathrm{x} 10=20$. Based on the questionnaire given to one sample, the score is 16 (sixteen).

Based on the percentage of data obtained through the formula used, the percentage of sample responses to the media booklet is the Percentage of Eligibility Criteria $=$ Total Sample Answer Score divided by Total Maximum Score x 100; thus, the score for the small group trial is $16 / 20 \times 100=80 \%$. Based on the table of eligibility criteria, the percentage value is in the range between $61 \%-80 \%$, which means that it is in the feasible range. Based on a small group questionnaire, it was found that as many as $100 \%$ of health cadres stated that the booklet picture display was quite clear, the booklet display increased interest in learning, could describe the actual situation, through this booklet it was easy to understand SDEIGD, and the booklet was entirely appropriate to use for health cadres.

A large group trial was conducted on 20 health cadres. The selected cadres were health cadres who had never been exposed to the SDEIGD guidelines or modules. The number of question items in the questionnaire is 10 , While the highest score for each item is 2 . The highest total score is 400 . This number is obtained from the highest weight $\mathrm{x}$ number of samples $\mathrm{x}$ number of questions, so $2 \times 20 \times 10=400$. obtained from the large group, sample answers to 20 students are 316. Based on the calculation of the percentage of the data obtained according to the formula used, the percentage of sample responses to the SDEIGD Booklet media: is the Percentage of Eligibility Criteria = Total Sample Answer Score divided by Total Score Maximum x 100. Thus, the score for the large group trial is 316/400 x $100=79 \%$. Based on the table of eligibility criteria, the percentage value (79\%) is in the range between $61 \%-80 \%$, which means that the quality of the test results in this range is in the decent/good/easy category. Based on the percentage of sample responses and the existing criteria, it can be concluded that the SDEIGD booklet is suitable for use by health cadres as a guide for the implementation of growth and development screening.

The data from the large group trial can be described as follows: as many as $100 \%$ of health cadres said that the use of media from text and images of SDIDTK booklets was interesting to see and read. It means that the images and text on the media foster interested in reading for those who see and study the module.

The cadres' understanding of the Stimulation, Detection and Early Intervention materials in the booklet were reviewed to understand through pre-and post-test evaluations. Cadre's understanding of the 
material in the SDEIGD booklet based on pre-and post-test scores increased from an average value of 31 to an average of 60.5 . There was an increase in knowledge of $95.16 \%$. Based on the pre-test scores, $80 \%$ knew how to measure growth, such as measuring height and weight, but $80 \%$ answered incorrectly about the meaning of growth, 65\% answered misunderstandings about development, $90 \%$ did not know the tools used to measure development, $80 \%$ do not know how to assess the development of toddlers, and as much as $65 \%$ do not know how to do the stimulation. When the post-test was carried out, it was seen that there was a very significant increase in knowledge. Almost half of the health cadres answered the definition of growth and development correctly, $60 \%$ answered correctly the tools used to measure and assess development, and $70 \%$ answered correctly regarding how to do the stimulation.

\section{Conclusion}

1. Based on the analysis of the needs and characteristics of health cadres on several aspects, including analysis of learning curriculum, analysis of learning resources, and analysis of development references, media is needed that can assist cadres in understanding the implementation of growth and development screening. The design of media development is based on the arrangement framework, according to Sadiman (2007). This design starts from analyzing the needs and character of cadres, setting learning objectives, compiling evaluation instruments, compiling media scripts, and conducting media trials.

2. The results of the validation of materials experts and linguists, it is known that the SDEIGD booklet media meets the criteria and is worthy of being a guide for health cadres in understanding Stimulation, Detection, and Early Intervention of Toddler Development.

3. The results of the media trial starting from small groups, large groups and understanding tests of the SDEIGD material indicate that the SDEIGD Media Booklet is worthy of being a handbook for health cadres to implement screening for toddler growth and development.

\section{Acknowledgement}

We would like to express our gratitude to the director of the Midwifery Department of Jambi health polytechnic who has supported this research.

\section{Conflict of Interests}

Author is not conflict of Interest.

\section{References}

Alifariki, L. O. (2020). Gizi Anak dan Stunting. Yogyakarta. Penerbit LeutikaPrio.

Arief Sadiman, D. (2007). Media Pendidikan (pengertian, pengembangan dan pemanfaatnya). In Jakarta Utara: Raja Grafindo Persada.

Attanasio, O. P., Fernández, C., Fitzsimons, E. O. A., Grantham-McGregor, S. M., Meghir, C., \& RubioCodina, M. (2014). Using the infrastructure of a conditional cash transfer program to deliver a scalable integrated early child development program in Colombia: cluster randomized controlled trial. Bmj, 349 .

Fernald, L. C. H., Gertler, P. J., \& Neufeld, L. M. (2008). Role of cash in conditional cash transfer programmes for child health, growth, and development: an analysis of Mexico's Oportunidades. The 
Lancet, 371(9615), 828-837.

Hendrawati, S., Mardhiyah, A., Mediani, H. S., Nurhidayah, I., Mardiah, W., Adistie, F., \& Maryam, N. N. A. (2018). Pemberdayaan Kader Posyandu dalam Stimulasi Deteksi dan Intervensi Dini Tumbuh Kembang (SDIDTK) pada Anak Usia 0-6 Tahun di Desa Cileles Kecamatan Jatinangor Kabupaten Sumedang. Media Karya Kesehatan, 1(1).

Kemenkes RI. (2016). Pedoman pelaksanaan stimulasi, deteksi, dan intervensi dini tumbuh kembang anak di tingkat pelayanan kesehatan dasar. IDAI.

Kemenkes RI. (2018). Rencana Aksi Kegiatan Direktorat Gizi Masyarakat Tahun 2015-2019. Direktur Jenderal Kesehatan Masyarakat Kementerian Kesehatan. https://e-renggar.kemkes.go.id/file2018/eperformance/1-465909-3tahunan-904.pdf

Khairunnisa, D. N., Handayani, D. S., Nirmala, S. A., Astuti, S., \& Judistiani, T. D. (2018). Faktor Predisposisi Bidan dalam Pelaksanaan Program Stimulasi, Deteksi Dini dan Intervensi Tumbuh Kembang (SDIDTK). Jurnal Sistem Kesehatan, 3(4), 198-203. https://doi.org/10.24198/jsk.v3i4.18498

Léger, J., Olivieri, A., Donaldson, M., Torresani, T., Krude, H., Van Vliet, G., Polak, M., \& Butler, G. (2014). European Society for Paediatric Endocrinology consensus guidelines on screening, diagnosis, and management of congenital hypothyroidism. Hormone Research in Paediatrics, 81(2), 80-103.

Maritalia, D. (2009). Analisis pelaksanaan program stimulasi, deteksi dan intervensi dini tumbuh kembang (SDIDTK) balita dan anak pra sekolah di Puskesmas Kota Semarang tahun 2009. Program Pasca Sarjana Universitas Diponegoro.

Padila, P., Andari, F. N., \& Andri, J. (2019). Hasil Skrining Perkembangan Anak Usia Toddler antara DDST dengan SDIDTK. Jurnal Keperawatan Silampari, 3(1), 244-256.

Palasari, W., \& Purnomo, D. (2012). Keterampilan ibu dalam deteksi dini tumbuh kembang terhadap tumbuh kembang bayi. Jurnal Stikes, 5(1), 30-40.

Permono, H. (2013). Peran orangtua dalam optimalisasi tumbuh kembang anak untuk membangun karakter anak usia dini.

Revika, E., Fitriana, Y., \& Andriyani, A. (2019). Pemantauan Kemampuan Anak Dalam Mencapai Tumbuh Kembang Yang Optimal Dengan Deteksi Tumbuh Kembang Pada Anak Usia 2-5 Tahun di TK Ulil Albab. Jurnal Pengabdian Masyarakat Karya Husada (JPMKH), 1(1), 6-12.

Sari, T. P., \& Haryanti, R. S. (2019). Ketrampilan Kader Posyandu Balita Tentang Stimulasi, Deteksi dan Intervensi Dini Tumbuh Kembang (SDIDTK). Proceeding of The URECOL, 297-302.

Soetjiningsih, C. H. (2012). Perkembangan anak sejak pembuahan sampai dengan kanak-kanak akhir. In Jakarta: Prenada.

\section{Copyrights}

Copyright for this article is retained by the author(s), with first publication rights granted to the journal.

This is an open-access article distributed under the terms and conditions of the Creative Commons Attribution license (http://creativecommons.org/licenses/by/4.0/). 